\title{
'Creating a Room of One's Own': French Farm Women, Agritourism and the Pursuit of Empowerment
}

\author{
Alexis Annes ** and Wynne Wright *
}

\author{
**Enseignant Chercheur \\ UMR LISST-Dynamiques Rurales / Ecole d'Ingénieurs de Purpan \\ 75 voie du TOEC \\ BP 57611 \\ 31076 Toulouse Cedex 3, France \\ Tel: (33) 561153086 \\ Email: alexis.annes@purpan.fr \\ * Associate Professor \\ Depts. of Community Sustainability and Sociology \\ 330 B Natural Resources Building \\ Michigan State University \\ East Lansing, MI 48824, USA \\ Tel: (517) 884-1372 \\ Email: wrightwy@anr.msu.edu
}

\begin{abstract}
This paper explores how farm women use on-farm tourism as a vehicle for empowerment within the context of family farms. We conceptualized this notion by drawing on Woolf's writings and on theories from the field of development. We draw upon qualitative data analysis of a farm women's agritourism network in southern France centred on sheep milk production for Roquefort cheese. We showed that by developing on-farm tourism and participating in this network, research participants were able to engage in the process of empowerment. These women found a room of their own and created a space of resistance in which they have conducted their own project. However, if the process of empowerment has been engaged, we showed that persistence of patriarchal culture and agrarian ideology slow down this process. This case study suggests that farm women have the possibility to conduct their project as long as it does not interfere with other farm activities controlled and managed by men.
\end{abstract}

Keywords: Farm women, Empowerment, Rural culture, Agritourism, Gender role, France, Case Study. 


\section{Introduction}

Invisibility has characterized the experience of women in agriculture (Barthez, 2005; Delphy, 1983; Nicourt, 2014; Rieux \& Dahache, 2007). Despite the fact that women have always been integral to food and fiber production, their participation in farming, especially because it took place within the context of the family, remained largely unnoticed (Delphy, 1983). French farm women's invisibility has historically been accomplished by both legal and socio-cultural means and can be traced to the contours of peasant society characterized by patriarchy and agrarian ideology (Clearly, 1989; Mendras, 1995; Segelan, 1983).

Results of the 2010 French agricultural census appear to challenge this conceptualization by shedding light on a demographic shift: more than one-fourth of all farm operators and/or co-operators are women, up from only eight percent in 1970. Likewise, onefourth of beginning farmers are women (Wepierre et al., 2012). Since the 1970s, women have altered their agricultural status through inclusion in legal frameworks meant to recognize and protect their interests which has allowed them to gain visibility and voice (Barthez, 2005;

Rieux \& Dahache, 2008). French law today allows women to be recognized as full farm partners.

Studies suggest that women tend to farm differently than most male operators (Dahache, 2014; Rieux \& Dahache, 2008). Today's farm woman may operate her own farm independently or may be a co-operating partner with another individual (typically husband). She is more often older than the average farmer - respectively 54 and 51 years old (Wepierre et al., 2012), more educated, and she tends to operate smaller and more diversified farming systems. Female operators are more often engaged in sheep and/or goat milk production, fruit and vegetable farming, or viticulture production (Wepierre et al., 2012). Women are also more likely to open their farm up to the public in the form of farm tourism (Brandth \& Haugen, 2011; Garcia-Ramon et al., 1995; Giraud, 2011). In fact, women are popularly 
claimed to bring new insights and sensitivities to agriculture in general, owing to what are perceived to be their 'unique' skills, knowledge and subjectivity. Headlines routinely now explore the meaning of this feminization of agriculture: Les femmes sont-elles l'avenir de l'agriculture (“Are women the future of agriculture”) (Groult, 2010, p.1)?; "Les femmes en agriculture: Le statut des femmes évolue et l'agriculture y gagne" ("Women in agriculture : The status of women evolves and agriculture gains") (Le Sillon, 2013, p. 1); or, Les agricultrices agissent pour l'avenir du monde rural ("Farm women act in favor of the future of the rural world") (Ouest France, 2012, p.1).

Recently, we (Wright and Annes, 2014) explored how farm women involved in agritourism can build bridges and foster dialogue between farming and non-farming populations. Yet, in this paper, our intent is to move away from assessing what farm women bring to agriculture, but to interrogate the benefits women acquire for themselves. Using the case of a farm women's agritourism network in southern France, we explore the question of women's empowerment, asking whether participation in farm diversification through agritourism allows farm women to exercise their agency and challenge patriarchy and agrarian ideologies.

Farm tourism has gained recent attention ${ }^{1}$, but is not new to agriculture. Much of rural Europe has used rural tourism as an economic stream for decades (Oppermann, 1996; Sharpley \&Vass, 2006). France introduced financial support systems to help redevelop old farm buildings into guest accommodations in 1954. However, it was only by the end of the 1970s, early 1980s, that it gained support from agricultural leaders. Currently, there is increased scrutiny of, and resistance to modern agriculture, creating space for new entrepreneurial climate (Muller, 2009; 1987). Agricultural leaders became wary that productionist agriculture could lead to undesirable consequences for national food production,

\footnotetext{
${ }^{1}$ Today, three percent of French farms are engaged in tourism (Lerbourg, 2013).
} 
ecological well-being, and cultural patrimoine, now stress a new production model based on the multiple benefits gained by agricultural diversity ("multifunctional agriculture").

Multifunctional agriculture valorizes production, but it also couples it with the production of other non-market related goods, such as health and nutrition, landscape, and cultural welfare. As a result, new farm activities - traditionally seen to be of little value ${ }^{2}$ - are increasing supported, such as on-farm processing, direct sales, and farm tourism ${ }^{3}$.

Multifunctional agriculture in general, and agritourism in particular, provided women new opportunities to invest in agriculture ${ }^{4}$. In fact, agritourism and gender often intersect.

Several studies show that farm women are frequently pioneers in this economic development initiative (Barbieri \& Mshenga, 2008; Busby \& Rendle, 2000; Garcia-Ramon et al., 1995; McGehee et al., 2007; Oppermann, 1995). Hosting visitors on the farm is suggested by the existing research to afford women the opportunity to move from a position of societal invisibility to assume roles that hold promise for personal empowerment (Cánoves et al., 2004). Brandth and Haugen (2010, p. 425) argue that "engaging in farm tourism implies a change that not only demands new skills and competencies, but may also influence the conditions under which gender relationships, power, and identities are enacted." Others (Evans \& Ilbery, 1996) have discovered it offers no changes in women's position. Sharpley and Vass (2006) found that farm women operating tourism initiatives in north-eastern rural

\footnotetext{
${ }^{2}$ Until then, these farm activities existed but only due to individual initiatives. Agricultural leaders actually did not consider these types of activities legitimate. See the work of Muller $(2009 ; 1987)$ for a more complete discussion of this point.

${ }^{3}$ Growth in farm tourism grew significantly when officials touted it as desirable for multifunctional agriculture and supplied subsidies to encourage its development. Benefits are often touted as numerous: it is often claimed to be a remedy for economic stress (Benjamin, 1994; McGehee et al., 2007); rural development (Butler, Hall, \& Jenkins, 1998; Ploeg et al., 2000), nature conservation (Lane, 1994), and cultural consumption (Bessière, 1998; Burton \& Wilson, 2006).

${ }^{4}$ Studies show that, in the 1960s, modernization of agriculture not only pushed farm women out of agriculture, but also from the countryside (Lagrave, 1996). The 1970s are characterized by a significant exodus of rural women - especially among unmarried women who ventured into nearby urban centers in search of employment. Bourdieu $(1962 ; 2002)$ contends that this female exodus had a significant impact on rural cultural norms, particularly related to marriage, land/patrimony transmission, and the farm division of labor.
} 
1 England to be highly motivated by job satisfaction and a sense of independence that farm tourism provides. They consider this an employment issue, however, we see this outcome as more of a socio-political issue. In the French context, it has been suggested that agritourism provides women with purpose, or a niche to fulfil on the farm (Giraud, 2004; 2007; 2011; Giraud \& Rémy, 2013). Giraud (2011) argues that while tourism allowed French women to realize autonomy and to give value to their skills, this autonomy is not unfettered; it occurs within a context of dependence. Women are free to chart their own space for creativity and income generation, yet only to the extent it is agreeable with their husbands. This alerts us to the importance of the broader social structure, such as patriarchy or agrarian ideology, in which tourism is pursed. Patriarchy and agrarian ideologies are lingering expressions of rural France. For instance, Saugeres (2002a; 2002b; 2002c) indicates that, under an agrarian ideology, farm women are perceived as "incomplete farmers." She examined the representation of farm women in the French Aveyron region - the same region where we conducted this study — and found that women are perceived as lacking an innate knowledge of farming and an embodiment to the land (Saugeres, 2002a), as well as inadequate physical strength to be competent farmers (Saugeres, 2002c). Thus, the extent to which involvement in farm tourism modifies these cultural representations and therefore dismantles agrarian ideology remains unsettled.

In this article, we explore how women, 'create a room of their own' on the family farm, or how women use agritourism to pursue empowerment. In seeking to examine the empowering effects of agritourism, we have two objectives. Firstly, this work contributes to the conceptualization of empowerment — a concept which has mainly been mainly used to understand the experiences of women in developing countries. This geographic lens allows us to add nuance to our understanding of this process. Secondly, we want to add to the literature on gender and farm tourism in general, and agritourism as a vehicle for women's 
empowerment, in particular. Most existing studies are based on field research in Anglo-Saxon and Scandinavian countries. Our research focuses on a French case allowing us to bring a Francophone perspective to the debate.

\section{Conceptualizing Empowerment}

The title of this paper references the work of English writer Virginia Woolf and her 1929 essay, A Room of One's Own. Woolf's writing is considered a classic feminist treatise on women's rights and basic needs (Brody, 2011; Coleman, 2012 Filimon, 2009; Lemaster, 2012). Woolf argues that women's empowerment comes from the acquisition of financial independence and a private (physical) space — a 'room of their own' (Filimon, 2009, p. 26) in which they can work for themselves apart from the demands of husbands, children or others and pursue their personal interests. Lacking of financial resources and/or access to private space, women remain oppressed by patriarchal ideologies and institutions that confer the demands of others upon them (Coleman, 2012).

A second scholarly work from Woolf_Mrs. Dalloway (1925)—adds to the conceptualization of women's experience of subordination in western societies and further refines our understanding of empowerment. In this text, Woolf highlights the everyday activities that constitute women's lives. According to Brody (2011, p. 10) this focus allows the Mrs. Dalloway character to "[bring] value to activities important to women that were otherwise trivialized or invisible." Herein lies a key dimension of empowerment - making visible in the public sphere women's abilities and skills performed in the private sphere. Capitalism and patriarchy often intersect in western societies to make women's work in the private sphere invisible. By rendering transparent that which is unseen, women's roles in both the productive and reproductive spheres can increase in value (Brody, 2011). 

by stressing the need for financial resources and space for self-expression, as well as the necessity of making visible women's mundane activities. Crucial for understanding the daily lived experience of rural women is an awareness of the significance of spatial dynamics. Historians have documented cases where farm women went months without interaction with others outside of the immediate household. Freedom to visit neighbors or kin, attend community meetings, or church services was infrequent for most rural women, creating the conditions for isolation that, in some cases, was excruciating (Fink, 1992). Cleary (1989) writes that farm life created considerable isolation for French women and this condition was exacerbated by agricultural modernization. In addition to the isolation structured by their remote living conditions and the farming lifestyle, agricultural modernization stripped women of common venues for social interaction. He writes that "[a]mongst the first victims of modernization have been places of female sociability - the communal water well or the village wash-house have vanished along with the local baker or butcher, replaced by the travelling between men and women and it also mandates that we scrutinize other patterns of domination 
1 Only once we have dismantled the inequalities embedded in these practices, can we initiate a power shift (Charlier, 2006; Kabeer, 1999; 2001).

For development scholars, empowerment is transformative; women become agents of their own transformation. However, it is important to note that empowerment is not an endstate, but a dynamic, on-going process (Kabeer, 2001). Drawing upon the work of Foucault, development scholars (Charlier, 2006; Oxaal \& Baden, 1997) identify four types of power: "power over", "power to", "power with," and "power within." "Power over" implies relations of domination and/or subordination. This type of power rests upon control and domination of one group over another and may be given freely or extracted illegitimately. "Power to" includes the ability to make decisions, have authority, seek solutions and exercise creativity. It acknowledges the importance of skills and competencies (human resources) as well as tangible resources. "Power with" underlies the notion of solidarity signaling the capacity to collectively organize in the pursuit of common goals. Lastly, "power within" refers to personal self-esteem, including the ability to see oneself as a change agent. Others suggest that "power inside" also refers to the cultivation of reflexivity or women's ability to identify the sources of their oppression (Afshar, 1998; Murthy et al., 2008).

In short, the expansion of agency is related to the acquisition of three of the four types of power: "power of," "power with," and "inside power" (Charlier, 2006; Oxaal \& Baden, 1997; Williams et al., 1994). Based on this conceptualization of empowerment, and fine-tuned by the inputs of the work of Woolf $(1925 ; 1929)$, we suggest that farm women's empowerment in the context of agritourism can be understood as the threefold process of: making decisions, acting upon them, and exercising creativity ("power to"), and, in this process, acquiring new resources and skills, as well as finding one's personal space on the farm; (2) being able to collectively organize to reach goals ("power with"), and, in this process, collectively gaining new resources and skills; (3) identifying sources of oppression 
and building self-esteem ("power within"), that can be approached as challenging dominant cultural representations and making visible in the public sphere abilities and skills performed in private.

In the following section, we present the case we use to explore farm women's empowerment in the context of agritourism.

\section{The Case: Réseau de Visites de Ferme}

Réseau de Visites de Ferme (RVF) is an agritourism network of farm women located in Aveyron, France, devoted to educating tourists about the technical and cultural aspects of sheep farming ${ }^{5}$. Agriculture remains central to the economic portfolio of Aveyron, employing 15-20 percent of the labor force (Frayssignes, 2011). Its origins lie in the small scale agropastoral system, but today it is known for highly specialized sheep farming which produces milk for the Roquefort cheese market. Roquefort is a blue cheese made of milk derived primarily from Lacaune sheep. Its distinctive blue-green vein is created by injecting penicillin and allowing the cheese to ripen in the limestone caves located beneath its namesake village Roquefort-sur-Soulzon.

The Network was launched in 1993 by two of its current members. Members welcome tourists to their family farms to provide a goûters à la ferme, or 'farm snack' - a popular form of farmstead hospitality in France (Bessière, 1998). The snack is accompanied by a guided tour where the host shares knowledge of milk production and the cultural heritage of sheep farming along with the natural amenities of the area that make Roquefort distinctive and globally recognized. Each member of the Network offers roughly the same services: first, the educational tour, then the snack, typically consisting of cheese, wine, and desert. Membership

\footnotetext{
${ }^{5}$ Aveyron belongs to the southern Midi-Pyrenees region and is a landscape of geological diversity composed of massive and craggy mountains, deep gorges, and serene meadows. The high limestone plateau known as the Grands Causses runs through the region and is made up of a series of underground caves.
} 
1 in RVF is contingent upon possessing a suitable 'old' barn in which to host guests. The

2 leadership of RVF prefer to keep the Network small; at its largest there were six members; currently there are four.

We use RVF as a case to explore the potentialities of agritourism for farm women's empowerment. The age of this Network (almost 20 years) is particularly relevant. This 20year experience allows for a better assessment of empowerment outcomes associated with membership. Moreover, as stated in the literature (Kabeer, 2001), empowerment is a dynamic process which is better observed over time.

To understand how the involvement of these farm women in RVF contribute to their empowerment, we focus on the following three questions based on our conceptualization of empowerment: (1) How does participation in RVF reflect abilities to design and manage their own economic activity? By carrying out this project, does it allow farm women to acquire financial independence and a space of their own on the farm? (2) How does participation in RVF help farm women reach their goals and to acquire additional skills? Finally, (3) how does participation in RVF contribute to challenging dominant cultural representations of farm women as well as reflecting adequately contemporary farm women's daily experience?

Related to this question is the issue of whether participation fosters women's confidence.

\section{Research Methods}

To answer these questions, we primarily used qualitative semi-structured interviews. In order to have an in-depth understanding of the Network, efforts were made to interview all the current members of the RVF network (four members). In addition, one former member was also interviewed as she had only recently resigned. Therefore, we interviewed a total of five women ranging in ages between 45 and 62. Four interviewees (three current members 
and the former member) are full-time farmers working with either their husband or son ${ }^{6}$, while the fourth member has the status of farm employee. The farms with which these women are associated range in size from 80 to 110 hectares and between 450 and 550 ewes are milked. All farms have been in their husband's family for at least three generations. In addition to being in charge of the farm tourism activity, the women also were responsible for milking the sheep twice daily. All women were also responsible for the management of the farm records, and some engage in other farm activities, such as poultry and gardening. Four out of the five interviewees had a previous career before becoming officially/legally involved on the farm ${ }^{7}$; three grew up on a farm, but none of them had formal agricultural training. Finally, two interviewees were among the founders of the Network, one entered it a couple of years after its creation, and another joined one year ago. This diversity provides a broader range of perspectives on experiences, motivations, and benefits associated with Network membership. Data were collected in 2012 and each of the five interviews were conducted at the respondent's farm and ranged in length from $1 \frac{1}{2}-4$ hours. Interviews were conducted in French, tape-recorded, and later partially transcribed and translated. Both authors were present for the interviews as was a language interpreter. Interviews consisted of approximately 40 open and closed-ended questions covering subjects such as farm history, farm and agritourism organization and interaction, motivations, gender dynamics, and future visions. In each case, researchers were also given a guided tour of the farm. Each respondent has been assigned pseudonym to shield her identity.

Interviews form the main source of data in our analysis, however, we also conducted participatory observation and document analysis. Each author assumed the role of tourist on two separate occasions and took part in a farm visit along with other guests. The visit allowed

\footnotetext{
${ }^{6}$ These four women are involved in a GAEC (Groupement Agricole d'Exploitation en Commun), a legal structure allowing two or more individuals to enter into a business partnership, sharing the decision-making, the work and the benefits (the contractees are considered as co-operators).

${ }^{7}$ Interviewees were involved in nursing, social work and secretarial work prior to marriage.
} 
us to observe the interaction between host and guests and to experience the visit as a tourist.

We also analyzed a number of documents such as advertising brochures and website. These data sources do not explicitly appear in the following results section. They mainly help allay challenges to internal validity by allowing us to better contextualize our understanding of this Network and to corroborate interview findings.

A general inductive approach to data analysis was used. Both authors systematically read and coded each transcript which resulted in the emergence of significant textual themes. The identified themes were analyzed based on their congruence with concepts from the empowerment literature.

Our research design provides us with an in-depth understanding of the experience of these five current/past members of RVF, yet, there are limitations to these data that should be noted. Given the small sample size as well as the homogeneity in our respondents', it is not possible to determine if these findings represent all women agritourism entrepreneurs. We offer these data to ignite further scrutiny of how empowerment unfolds via women's involvement in farm tourism. In particular, we believe this case offers relevant insights on factors both contributing to, and thwarting, empowerment.

\section{Findings}

In this section, we analyze how involvement in agritourism contributes to empowerment. We specifically focus on the origin of the initiative and daily operations which demonstrate that, through farm tourism, women are able to create a space of their own on the farm allowing them to gain "power to," "power with" and "power within."

\section{"Power to":}



abilities of women to conduct and manage their own economic endeavor, and, by carrying out this initiative, does it allow them to acquire financial independence and a space of their own on the farm? We examine agritourism motivations as well as strategies for realizing this goal. We specifically the acquisition of material resources and of space. Upon marriage each of the women settled onto their husband's farm where he, along with his immediate family, resided. Three of the five women, literally moved into the same dwelling with their new in-laws, which was typical of French farm families until the 1970s (Bourdieu, 1962; Mendras, 1995). Three had been raised on a farm, but none of them intended to become farmers. At the time of marriage, all but one was employed in the local village.. After some years on the farm, each of the women began to adopt tasks to contribute to the overall welfare of the farm. They gradually left their paid jobs and devoted increasing time to child rearing, household maintenance, and farm activities typical of French women, such as milking the sheep, bookkeeping, and assisting their husbands and/or sons with the birthing of lambs. Over time, they each became an official full time farm co-operator. Each, however, also accentuated a sense of loneliness and isolation that they experienced on the farm.

Repeatedly, respondents bemoaned the limited social networks and their desire for increased human interaction. Jeanne explains: women to initiate their agritourism business. Each entrepreneur launched their business once

I was a nurse. Of course, I had the kids, but, at home, at times, I was bored! It was important for me to have relationships. I thought that creating this activity -welcoming people to the farm - would help me to recreate those relationships I was missing. When I was a nurse, I really enjoyed interacting with other people. Then, I ended up on a farm, milking sheep, taking care of lamb births... you know, a ewe does not speak too much!

The desire to conduct a project - something that they could call their own - motivated the their children were older. 
My children were older, less demanding. On the farm, my husband and I were in a routine where there was not too much work for me. I also wanted to meet people. I needed social interaction (Nathalie).

There is also the fact that at some point, there is a time when the kids are grown up, when the farm is under a cruising mode, when there is less work...then, for a lot of women, it [agritourism] is a way to meet the outside world, to do something, to conduct a project (Véronique).

To our surprise, generating additional income on the farm was not the primary motivation for launching this agritourism activity. As expressed by Véronique, their motivations were not only to meet people outside the farm, but also to "conduct a project" of her own, in order to find legitimacy - a sense of purpose on the family farm. Nathalie echoes this sentiment when she says: "it makes you feel valuable to conduct a project. It makes all human beings [feel] valuable."

Once the personal decision was made to embark upon agritourism, each of the women set about amassing appropriate resources; the first was the husband's consent.

My husband was into farm unions, he asked a lot of support from me. I received a lot of people here, at home, I had to stand in for him on the farm. I was telling him that I needed my own activities, my own projects! He would tell me: "For God sake, why can't you stay home? (Jeanne)

Jeanne's husband's lack of enthusiasm did not stop her from proceeding, but in order to do so she had to negotiate traditional gender expectations.

I am well organized. If I leave my house, my bedroom is tidy, meals are ready, everything needs to be planned ahead. It's just a question of organization, otherwise, you know, people could say that Jeanne did this or that, went to this place or that one, but when it comes to her own house...

Similarly, Nathalie faced strict gender expectations not only from her husband, but her inlaws. She wanted to enroll in a cheese-making course requiring her to leave the family and go to northern France for four months. Her in-laws expressed concern, fearful of neighbors would say if she left her family for such a period. 
Once acceptance was granted, each of the women embarked upon acquiring material resources. They each first negotiated with their husband's - and in some cases, their in-laws for the use of the old stone barn on the property. These barns were typically being used as storage facilities since they were no longer suitable for modern-day sheep production. The barns became both their own physical space to conduct their agritourism work as well as representative of a symbolic space to exercise their own autonomy and creativity. Jeanne articulates well the freedom she had to stage her barn to her own liking without interference: My husband did not disagree with the project. He was thinking about it too. He had his own idea on what to do and how, but he let me set up my project alone. The first year, there was still hay in the barn because of the cold [weather]. With the money I had, I had electricity installed and I restored the main room. This money was my money. It was not farm money. I set up my account. I have always had a separate account for my visits. With the money I had, I always managed to do what I wanted. Jeanne's statement emphasizes that launching her business required both physical space and financial income. Using her personal income gave her autonomy, echoing Woolf's (1929) call for women to have a "room of one's own" and "money of one's own" if they are to be less subordinated to men. Through the development of agritourism, farm women created a "space of resistance" within patriarchal and agrarian structures where they could express themselves. They were able to chip away at the isolation that had plagued them for years and find their own outlet affording social interaction, creativity, and income generation.

Most of the women held to cultural convention and restored their barns with traditional elements customarily found in an old barn. Antique scythes, wagon wheels, and ox yokes are often hung on the walls as works of art. Each of the women also attempted to evoke a very rustic, traditional imagery of old world France, but each of the women have also customized the space and used the venue to imprint her personality. Madeleine displays her fossils connection; Brigitte sells her homemade jams; Nathalie shares her past-time with visitors by hanging from the ceiling rafters a large Harley Davidson® Motorcycle flag, and, Veronique 
installed a modern (and state-certified) kitchen and toilets to rent her barn for other catering events.

While all barns have in common their age (built circa 1850-1880) and their

architecture (limestone harvested from the region), inside, they differ as they reflect the diversity of their caretakers. In this way, the women of RVF have acquired "power to" define their goals, to act upon them, and to express creativity (Charlier, 2006; Oxaal \& Baden, 1997; Williams et al., 1994).

\section{'Power with':}

Empowerment should not only be considered as an individual process, it should be also approached as a collective journey (Charlier, 2006; Kabeer, 2001; Umut Bespiran, 2011). In this section, we want to understand how agritourism helps participants reach their goals and to acquire new resources as well as additional knowledge and skills. We discuss the collective nature of participation in RVF by examining the social relationships of our interviewees and the knowledge participants gained from this Network.

Our research shows that, even if the RVF members received only modest economic capital from their farm tourism, they acquired invaluable social, human and symbolic capital. Much of the revenue stimulated is devoted to barn restoration and covering other expenses; they do not generate large sums. Even among those hosting the most tourists annually around 3,000 guests - their profits contribute no more than ten percent of the total farm income. But, the women were adamant that it was other non-financial resources that drove them. Madeleine explains:

My neighbors, they tell me that it looks like so much work. They only see this side. It's hard work, it's true, but it's also a satisfaction. Interactions are so important! It's so important to be able to interact with people from everywhere. 
1 Each of the women echoed Madeline's assessment; participants were driven to launch their

initiative by the desire for social interaction. The opportunity to interact with visitors and to "travel the world while staying at home", as Jeanne put it, was their primary impetus for opening their farms to the public. Feelings of isolation and lacking a sense of purpose on the farm motivated the women to develop their business. They could have embarked upon farm tourism alone, but these women joined the Network because it also afforded them the chance to develop relationships with like-minded women. Nathalie explains:

Being in the Network allowed me to feel less isolated; I was with people who knew this activity. I gained and saved time. Also, a network is always a strength. The Network is well-known ... They [the members of the Network] knew about farm tourism; they had knowledge to share, and it fitted with what I wanted to do.

Members were welcomed into a Network that was highly regarded and had considerable knowledge about how to organize a successful agritourism operation. This was no small asset according to the respondents. The possibility of being mentored by experienced entrepreneurs meant that skill development could proceed quickly and much time and energy could be saved. In the early days, however, the originators -Madeleine and Jeanne - participated in programs offered by the Parc Régional Grands Causses which provided invaluable resources and training opportunities. They were assisted in grant writing which awarded them funding to help offset the costs of barn renovation, but the fundamental training was something they all emphasized as critical to their personal development and confidence.

Jeanne articulates the types of knowledge they acquired:

"They [trainers] explained to us the type of tour we should give to people. They taught us how to organize a visit, how to explain, how to create a tour, a snack, how to have people taste our produce. [With this new knowledge] we were able to develop three different types of visits."

In addition to acquiring knowledge about farm tour organization, membership in the

Network also allowed women to gain technical knowledge of cheese, its production and proper tasting qualities. Now, older members pass this down to newer members when they 
enter the Network, in this way reproducing cultural and techno-scientific knowledge. Nathalie remembers:

It [being in the Network] brought me a lot of knowledge about cheese. When I entered, there were four of us, and the Network had been going on for more than 15 years. They shared with me a lot of information and knowledge which they had put into practice for many years. [They taught me] how they welcome people, the way they were doing the snack, etc. At the beginning, I visited all of the farms to see how they were doing things.

Evident from the comments above and those of other members is the role that the Network played, to forge bonds of community. These relationships helped them create the solidarity needed to overcome isolation and assist each other in organizing their operations demonstrating their ability to exercise "power with" (Charlier, 2006; Oxaal \& Baden, 1997; Williams et al., 1994).

\section{'Power Within':}

Empowerment is not only about defining one's goals and acting upon them, it is also about cultivating and exercising "power within." It requires the ability to be reflexive about one's circumstances which can lead to an understanding of opportunities for growth, as well as awareness of the sources of their oppression. Therefore, we analyze the degree to which participation in RVF helps members challenge dominant cultural representations of farm women and reveals the complexity of their everyday experience. We also address whether this participation may foster women's self-esteem.

We must begin by reinforcing what may appear obvious, but the very visibility of farm women is far from insignificant. As farm tourism entrepreneurs, the women are no longer relegated to the sidelines of agriculture and considered 'farm help' (Barbieri \& Mshenga, 2008; Brandth \& Haugen, 2010; Jennings \& Stehlik, 1999; Mendras, 1995), but they are clearly visible and able to use tourism to craft a professional image and demonstrate 
specialized knowledge and authority to the public. Agritourism not only provides an opportunity to challenge dominant representations, but it also provides a chance to appear as agricultural professionals. As shown by Saugères (2002a; 2002b; 2002c), French farm women are often perceived as "incomplete farmers." The tour given by the women is an opportunity to demonstrate their knowledge of agriculture and to challenge this traditional image.

A professional identity is constructed at the very onset with marketing materials that work to de-emphasize farming and farm tourism as a way of life, or hobby, but as a "profession". The brochure reads, "Animated by the desire to share their passion for their job, four agricultrices' [farm women] invite you to discover their job in all its richness/intensity." Historically, farm women were referred to as a paysanne or fermière. Around the mid-century - during rapid adoption of industrial farming methods, the modern label of agriculteur began to be applied to farmers who embraced production for commercial markets with intensive and scientific methods (Bessière, 2012). At the same time, a woman similarly engaged in commercial agriculture began to be referred to as an agricultrice. By invoking the label agricultrices, Network members align themselves with this professional, modern status. A professional identity was reinforced by each member, but was most noticeable among those younger who appeared eager to construct a professional agritourism business. Nathalie left her husband, two sons, and the family farm for four months to attend cheese school due to her belief that proper training was crucial. Professionalism is also accompanied by the assertion of independence and autonomy. Women resisted traditional roles where they were ascribed to subservient tasks. Perhaps the most forceful in her demand for autonomy was Veronique who agreed to "work on the farm and in agritourism only if [she] was in charge to the same degree as [her] husband and brother-in-law."

Each of the members saw themselves as the primary agritourism entrepreneur and the husband as secondary. This relocates women in positions of authority and demotes men to the 
role of helper. Even though Veronique claimed her husband was an equal partner, she described his role as being primarily confined to maintenance and repair. His regularly occurring visible role was to entertain tourists; when she removes herself to retrieve the snack he performs a sheepdog demonstration.

According to Brigitte, she and her husband also embarked upon agritourism as a partnership. They divide leadership of the tours even though rural gendered norms frown on this work for men:

My husband likes leading the tours, but he says that most farmers around here would not, rural areas are patriarchal where men drive tractors and women milk. Other farmers would make fun of him if they knew he hosted visitors on the farm...I don't consider welcoming guests as feminine. My husband prepares flowers and jam, but some do.

These cases suggest that women's professionalism in agritourism casts men in secondary roles. Now men play the part of 'helper' and assist in uncompensated work.

Facility with science and technology is another way in which women demonstrate professionalism. Farm women conduct the tour in ways that demonstrate a vast knowledge of complicated social, biological, and technological processes. Tours highlight state-of-the-art buildings equipped with the latest technology, such as milking machines and hay driers.

Women commonly reported that the guests were unprepared to see such 'modern' technology and production practices. Madeleine said, "when they arrive they are surprised to see the way we work, the buildings, the milking room. They see the milking room tiled and they say 'it's a real lab that you have." Veronique's overview shows how she disseminates highly technical information.

I start it in the area where we dry hay where there is enough space and were I set up explanatory posters. There, I explain how to manage a sheep herd. Everyone can ask questions. I explain everything, births, lambs' sales, why milk control, old ewe's sales - the entire production cycle. Then, I tell them about the principle of in-door hay drying which takes place right behind them, the feeding of the sheep. Then we walk across the sheep barn itself, I tell them why there are different areas, how it works. I start the automatic feeder to show them how it works. After, I go into the milking room where I start the milking machines so that they can see how it works and we take advantage of this moment to speak about what happens with the milk and its process 
into Roquefort cheese. We speak about the milk, its components, all the sanitary controls, traceability, the arrival of the milk into the cheese factory then the Roquefort caves.

Each of the women showcased state-of-the-art production practices and reinforced adherence to quality assurance standards. Guests were exposed to stainless steel bulk tanks that store milk at precise temperatures, equipment used to test milk for pathogens, and machines that can milk 500-600 sheep in an hour. They are shown posters that detail scientific nutritional formulas that vary by the season; they are instructed on the importance of lactation cycles, genetic improvements, and artificial insemination. Veronique incorporates a PowerPoint presentation that explains the origins of Appelation d'Origine Contrôlée (AOC) regulations for Roquefort. Jeanne recounts the program of selective breeding that has improved milk production over the last 20 years and Madeline adds fluency in international agricultural policy when she discusses farm subsidies.

To this vast body of knowledge, the women are also able to share culinary acumen that is equally in demand. Madeleine explains with pride that:

Everybody wants my recipe for 'pain d'épices' jam. I give a lot of recipes! Even recipes they did not try. For example, I tell them to try the Roquefort and leaks quiche, to take a fig, stuff it with Roquefort and put it in the oven. It's delicious! After that, people send me emails. Sometimes, I can't even reply to all of them!

Within the household, Madeleine's culinary prowess might have gone unrecognized or trivialized, but an audience for her skills has provided her with a new avenue in which to enhance her confidence.

Presenting themselves as professionals within sheep industry rather than as "helpers" is not the only challenge to dominant representations that agritourism affords. Our interviewees also position themselves against dominant, idealized, even romanticized, representations of farmers. The farm women reveal themselves through their bodies by dressing to look the part of an authentic farmer. Some agritourism operators find it useful to wear culturally specific attire to evoke some desired sentiment (Brandth \& Haugen, 2010), but 
the women in the Network eschew costumes in favor of modelling a twentieth-first century representation of a farm woman. Veronique is often told by guests that they did not expect to "meet a farm woman looking like [her]. Maybe they were expecting someone older.. They tell me that they were not expecting a modern, dynamic woman like me." Nathalie also manages an impression of herself bent on challenging conventional representations:

Sometimes the kids tell me they want to see the fermière [farm woman]. I tell them I am the fermière. It is true that in kid's books the fermière is more likely to appear with a scarf holding a basket. I think there is a difference for some people between what they expect and what they see... I wear a pair of jeans and a t-shirt ... personally I think we should show people that they are not arriving where bouseux [nednecks] live.

In a similar defensive vein, Madeleine adds that she wants them to know that she is not "bagnard," or a convict, that she is not chained to the farm toiling endlessly, but enjoys the same activities as urban residents. "Before coming, they have a lot of clichés in their mind...Parisians still see us with clogs and boots." Just as the enacting of professionalism and a diverse skill-set reinforces one's sense of self, so too does the opportunity to lower personal masks and reveal their true selves. Woolf contends that making public the mundane, taken-for-granted, and invisible is a crucial step toward empowerment (Brody, 2011). Under patriarchy, only men's work (outside the household) is valued and women's private work is under-valued and often invisible (Coleman, 2012; Delphy, 1983). By welcoming tourists on their farm, Network members showcase the reality of their lives. Sophie makes an effort to ensure guests have an authentic experience. "I try to have them understand that we work here... We clean up, but it should not be too perfect...it is a working farm." Jeanne punctuates the multiple demands modern women have on their shoulders by communicating the multi-tasking she does. When they call for an appointment, I tell them "that they cannot come 30 minutes late because otherwise I would be late to complete my other chores like the milking."

Each of the women also reported having their tours interrupted by family members from time to time. Children barge in with a question, husbands stop by to greet the guests, 
1 phones ring, and oven timers buzz forcing women to briefly excuse themselves to tend to other responsibilities. Such disruptions bring to light the numerous activities that require women's attention and, at the same time, communicate a blurring of productive and reproductive spheres.

Challenging persistent cultural representations and offering a more authentic image of their lives gives our research participants more "power within", allowing them to see themselves as agents of change on their farm. Women additionally noted improvements in their self-esteem once they realized they were capable of managing their own business. Véronique, reflecting on her experience before and after she launched her business, explains: "I was not the same person. I was staying at home, I was working on the farm without being paid and without opening my mouth. Now, it's different... I am like Roquefort cheese, I have character!"

\section{One Step Forward, Two Steps Backward?}

The acquisition of "power to," "power with," and "power within," demonstrates a growing empowerment of the farm women of RVF. Within a patriarchal environment, where heterosexism and agrarian ideology persist, these women created spaces of resistance. As suggested by Woolf (1925), these women found in an old tattered barn a place where they can express their creativity and pursue their goals. The extent to which this barn constitutes a space of resistance could be questioned, however. In fact, existing literature suggests that empowerment is also about changing power relations between men and women as well as other socio-cultural structures of domination (Ali, 2013; Longwe, 1990). If this activity allows women to challenge cultural representations of farm women which portray them as incomplete farmers and/or reduces them to farm helpers, other unequal power relations persist which may impede empowerment. 

their own" on the farm. However, they could not have done so without their husband's accommodation - this questions the extent to which they can define themselves, their

objectives and act upon them. For example, Véronique states that: "It would be hard for a

woman to set up such an activity if her husband disagrees with it." Madeleine recalls

previous members who were forced to leave the Network due to spousal disapproval.

In the past some women left the Network because they got involved without really their husband's consent. So, they [the husband's] were fed up with seeing people "parading" on their farm. They did not like it! For example, Christine Delmas left because of disagreements with her brother-in-law. Another, Monique Courderc, quit because her son was making his own cheese, so she did not have any more possibilities to welcome guests.

The women mentioned above abandoned their goals because it conflicted with activities led

by males. The case of Huguette Labarde is particularly telling:

Huguette Labarde set up all the activity to launch her farm tourism business. She has a very nice old mansion, a real beauty. [The first time she hosted tourists] her husband...he saw one bus in his farmyard... He told her: "listen, this was the first bus, it's also going to be the last one." When he saw all these people being unloading from the bus, he didn't like it. She cried. She had done everything with us. She had bought the fabric for tablecloths, plates, glasses (...). It was hard for her.

These cases show that, for farm women, the creation of a "space of their own" is contingent upon male approval. Even though women created and maintained their own personal space for income and creativity expression, its presence was contingent upon the good will of their husbands, sons or brothers-in-law ${ }^{8}$. Huguette's experience also reminds us that farm property is also considered male property. Should agritourism activity conflict with farming activities controlled by men, it might come to an end. If, to the view of male family members, the tourism activity is the domain of women, this activity remains secondary. This finding echoes existing literature on the different values attributed to farm work. Even if such diversification

\footnotetext{
${ }^{8}$ Our data do not allow us to conclude why certain men would authorize women to conduct agritourism. We can hypothesize that individual characteristics as well as age, parental education, educational training, involvement in organizations outside the farm, previous employment might be responsible.
} 
1 is perceived as a remedy for economic stress, it is frequently de-valorized in comparison with

traditional farm work (Giraud \& Rémy, 2013).

In addition, women in the Network reproduce traditional gender roles by welcoming, nurturing, serving, and cooking for the guests. In this way, their present organization of farm tourism may not foster the social change needed to inspire empowerment. This reproduction of traditional gender roles reinforces the consequences of the modernization of agriculture which assigns women to the domestic sphere (Giraud \& Rémy, 2013). Moreover, when it comes to explaining why the Network is only made up of women, essentialist arguments about women's skills arise. Madeleine suggests that: “we [women] have a charisma, a feminine sensibility...that people tell me that I pass on the passion of our profession." Reflecting on the same issue, Brigitte says: "I think that we [women] have a sensitivity, something different that men don't have." In both cases, the women explain involvement in farm tourism using inherent characteristics perceived to be shared among all women. They use similar essentialist descriptions to explain men's lack of interest or involvement in farm tourism. Nathalie explains:

Often, in this region, what's related to agritourism is related to women. Ok, it's true that first of all, it's a question of time, I don't go work into the fields. So, the time I am here, I can welcome people. And also, men are more bad-tempered. I am here, so it's not a problem.

Such explanations tend to position individuals into mutually exclusive categories which become reified over time and used to justify unequal opportunities. By perpetrating this essentializing discourse, the women were unable to identify the source of their oppression, which can limit their ability to act upon it, or to cultivate, "power within."

\section{Conclusion}

The objectives of this paper were (1) to contribute to the conceptualization of empowerment, and, (2) to add to the literature on gender and tourism by specifically looking 
at agritourism as a potential vehicle for farm women's empowerment. We have shown that involvement in farm tourism has both contributed to farm women's empowerment and reproduced challenges to empowerment.

In order to conceptualize empowerment, we combined the work of English writer Virginia Woolf with the model put forward by development scholars which implies three types of power - "power to," "power with," and "power within" - that facilitates empowerment. We showed that through participation in the Network and the management of farm tourism, farm women experienced "power to" conduct and assume responsibility for their business and exercise creativity. Membership in the Network also facilitated "power with" through the creation of solidarity. Participants found support, shared experience, skills and new knowledge. Lastly, in the Network, they cultivated "power within" by developing self-confidence and challenging dominant representations portraying farm women as "incomplete farmers" that reduced them to the role of farm helper. In fact, they are able to craft a professional image by demonstrating specialized knowledge and authority to the public. Through their professional interaction with the tourists, they revealed the reality of their everyday experience.

However, if the process of empowerment has been engaged, the persistence of a patriarchal culture and agrarian ideology also mitigates this development. Our data suggest that empowerment potential is constrained and calls to advance farm tourism as a vehicle for women's empowerment may be overstated. In line with the scholarship of Giraud (2011), our findings substantiate the notion that farm women experience autonomy, within dependence. In other words, the women were able to pursue and realize autonomy but not as fully as they desired - they also navigated structures meant to constrain their agency. In fact, as suggested by Nazneen et al., "developing a sense of agency does not necessarily lead to loosening patriarchal structures" (2014:55).The women in this study demonstrate that their ability to 
pursue farm tourism is contingent upon male approval, a recognition of the persistence of "power over" women. Male approval is contingent upon the lack of interference with primary farming activities controlled and managed by men. It is also contingent upon the maintenance of traditional gender performances that reinforce the smooth functioning of primary agricultural work. In other words, the activity must refrain from disrupting men's work, family meal preparation, household work, or other farm chores assigned to women.

In this paper we have focused our lens on the empowerment potential of farm tourism given the accolades often bestowed upon this strategy as a tool for rural economic development. This question clearly requires more empirical research and may be expected to differ by region, the presence of competing economic opportunities, or tourism type. Also, results may be expected to differ based on respondents' personal characteristics. Studying the experience of farm women who operate as sole operator, or as co-operator with other women, might bring different insights. In fact, fostering the empowerment process of farm women may be contingent upon redefining the heterosexual couple as the household norm and as the pillar of French modern agriculture. In other words, women are unable to share power with men when their activity takes place within the family farm unit. The family farm as a mode of production, blurs the line between domestic and professional spheres, allowing circulation and therefore mutual reinforcement of long standing patterns of oppression from one sphere to another. Breaking this legacy is a pivotal step toward empowerment.

\section{Acknowledgements}

An earlier version of this paper was presented at the ARPEGE Workshop, Genre et Empowerment, University of Toulouse, February 14, 2014. Appreciation is extended to members of this workshop for their feedback. Support for this research was contributed by Michigan AgBioResearch and a SMI grant from the Institut National Polytechnique of Toulouse. 


\section{Reference list}

Adekanye, T. (1984). Women in agriculture in Nigeria: Problems and policies for development. Women's Studies International Forum, 7, 6, 423-431.

Afshar, H. (1998). Empowerment in the discourse and practice of development. In H. Afshar (Ed.), Women and empowerment: Illustrations from the third world. London: Palgrave Macmillian.

Ali, R. (2013). Empowerment beyond resistance: Cultural ways of negotiating power relations. Women's Studies International Forum, http://dx.doi.org/10.1016/j.wsif.2013.05.019.

Annes, A. \& Redlin, M. (2012). The careful balance of gender and sexuality: Rural gay men, the heterosexual matrix, and "effeminophobia." Journal of Homosexuality, 59, 2, 256-288.

Barbieri, C. \& Mshenga, P. M. (2008). The role of the firm and owner characteristics on the performance of agritourism farms. Sociologia Ruralis, 48, 2, 166-183.

Barthez, A. (2005). Devenir agricultrice : À la frontière de la vie domestique et de la profession. Economie Rurale, 289-290, 30-43. . (1982). Travail, famille et agriculture. Economica : Paris.

Benjamin, C. (1994). The growing importance of diversification activities for French farm households. Journal of Rural Studies, 10, 4, 331-342.

Bessière, C. (2012). Paysans et Agriculteurs. In A. Bevort, A. Jobert, N. Lallement \& A. Milas (Eds.), Dictitonaire du travail (pp. 530-536). Paris : PUF Quadrige. . (2008). 'Travailler à l'extérieur' : Des implications ambivalentes pour les compagnes d'agriculteurs. Nouvelles Questions Féministes, 27, 2, 53-66.

. (2004). 'Vaut mieux qu'elle travaille à l'extérieur !' : Enjeux du travail salarié des femmes d'agriculteurs dans les exploitations familiales. Cahiers du Genre, 37, 93-114.

Bessière, J. (1998). Local development and heritage: Traditional food and cuisine as tourist attractions in rural areas. Sociologia Ruralis, 38, 1, 19-34.

Boserup, R. (1970). Woman's role in economic development. London: Earthscan.

Bourdieu, P. (2002). Le bal des célibataires : Crise de la société paysanne en Béarn. Paris : Éditions du Points. 

. (1962). Célibat et condition paysanne. Etudes Rurales, 5/6, 32-136.

Brandth, B. (2006). Agricultural body-building: Incorporations of gender, body and work. Journal of Rural Studies 22, 4, 17-27.

Brandth, B. \& Haugen, M.S. (2011). Farm diversification into tourism - implications for social identity? Journal of Rural Studies, 27, 35-44. . (2010). Doing farm tourism: The intertwining practices of gender and work. Signs: Journal of Women in Culture \& Society, 35, 2, 426-446.

Brody, S. (2011). Law, literature, and the legacy of Virginia Woolf: Stories and lessons in feminist legal theory. Texas Journal of Women \& the Law, 21, 1-45.

Burton, R.J.F. \& Wilson, G. A. (2006). Injecting social psychology theory into conceptualization of agricultural agency: Towards a post-productivist farmer self-identity? Journal of Rural Studies, 22, 1, 95-115.

Busby, G. \& Rendle, S. (2000). The transition from tourism on farms to farm tourism. Tourism Management 21, 6, 635-642.

Butler, R., Hall, C. M., \& Jenkins, J. M. (1998). Tourism and recreation in rural areas. Chichester: Wiley.

Cánoves, G.,Villarino, M., Priestley, G.K., \& Blanco, A. (2004). Rural tourism in Spain: An analysis of recent evolution. Geoforum 35, 6, 755-69.

Charlier, S. (2006). L'analyse de l'empowerment des femmes qui participent à une organisation de commerce équitable. Une proposition méthodologique. In C. Auroi et I. Yepez (Eds.), Economie Solidaire et commerce équitable. Acteur et actrices d'Europe et d'Amérique latine (pp. 87-110). Louvain : Presse Universitaires UCL/IUED.

Coleman, L. (2012). Woolf and feminist theory: Woolf's feminism comes in waves. In R. Bryony \& L. Goldman (Eds.), Virginia Woolf in context. (pp. 79-91). Cambridge: Cambridge University Press.

Dahal, S. (2013). Power, empowerment and community radio: Media by and for women in Nepal. Women's Studies International Forum, 40, 44-55.

Delphy, C. (1983). Agriculture et travail domestique : La réponse de la bergère à Engels, Nouvelles Questions Féministes, 5, 3-17.

Doss, C. (2001). Designing agricultural technology for African women farmers: Lessons from 25 years of experience. World Development, 29, 12, 2075-2092.

Evans, N. \& Ilbery, B. (1996). Exploring the influence of farm-based pluriactivity on gender relations in capitalist agriculture. Sociologia Ruralis, 36, 1, 74-92. 
Filimon, E. (2009). Virginia Woolf in her writing room. Scientific Journal of Humanistic Studies, 1, 1, 25-28.

Frayssignes, J. (2011). System IV: Roquefort Cheese (France). In E. Barham and B. Sylvander (Eds.), Labels of origin for food: Local development, global recognition (pp. 177-183). Wallingford: CAB International.

Garcia-Ramon, M.D., Canoves, G. \& Valdovinos, N. (1995). Farm tourism, gender and the environment in Spain. Annals of Tourism Research, 22, 2, 267-282.

Giraud, C. (2011). Les voies de l'autonomie féminine. In Gilles Ferréol (Ed.), Femmes et agriculture (pp.89-100). Bruxelles-Fernelmont : EME \& InterCommunications. . (2007). Recevoir le touriste en ami : La mise en scène de l'accueil marchand en chambre d'hôtes. Actes de la Recherche en Sciences Sociales, 170, 5, 14-31. . (2004). Division du travail d'accueil et gratifications dans les chambres d'hôtes à la ferme. Cahiers du Genre, 37, 71-91.

Giraud, C. \& Rémy, J. (2013). Division conjugale du travail et légitimité professionnelle, Travail, Genre et Société, 30, 157-173.

Groult, Y. 2010. Les femmes sont-elles l'avenir de l'agriculture ? Le Web de la Terre. Retrieved July 11, 2014. Available at : http://www.laterre.fr/article.php3?id_article=661\&var_recherche=agricultrices

Hervieu, B. \& Purseigle, F. (2008). Troubled pictures: French agriculture and contemporary Rural Sociology. Rural Sociology, 73, 4, 660-683.

Hervieu, B. \& Viard, J. (2011). L'Archipel paysan: la fin de la république agricole. La Tour d'Aygues : Editions de l'Aube.

Jennings, G. \& Stehlik, D. (1999). The innovators are women: The development of farm tourism in Central Queensland, Australia. In One world, one community, one mission: Conference proceedings of the 1999 annual ISTTE conference, (pp. 84-98). Vancouver, Canada.

Kabeer, N. (2001). Conflicts over credit: Re-evaluating the empowerment potential of loans to women in rural Bangladesh. World Development, 29, 1, 63-84. (1999). Resources, agency, achievements: Reflections on the measurement of women's empowerment. Development \& Change, 30, 435-464.

Kazyak, E. (2012). Midwest or lesbian? Gender, rurality, and sexuality. Gender \& Society, $26,6,825-848$.

Lagrave, R.M. (1996). Celles de la terre. Paris: EHESS.

Lane, B. (1994). Sustainable rural tourism strategies: a tool for development and conservation. In W. Bramwell and B. Lane (Eds.), Rural tourism and sustainable development: Proceedings of the second international school on rural 
development (pp. 102-111). Clevedon: Channel View.

Lemaster, T. (2012). Girl with a pen: Girls' studies and third-wave feminism in a room of one's own and 'Professions for women.' Feminist Formations, 24, 2, 77-99.

Lerbourg, J. (2013). Diversification des activités. Agreste Primeur, 302, 1-8.

Le Sillon. (2013). Les femmes en agriculture: Le statut des femmes evolve. Juillet.

Little, J. (2003). Riding the rural love train': Heterosexuality and the rural community. Sociologia Ruralis, 43, 4, 401-417. . (1997). Constructions of rural women's voluntary work. Gender, Place \& Culture, 4, 2, 197-210.

Little, J. \& Panelli, R. (2007). 'Outback' romance?: A reading of nature and heterosexuality in rural Australia. Sociologia Ruralis, 47, 3, 173-188.

Longwe, S. (1990). Gender awareness: The missing element in the third world development project. In T. Wallace \& C. March (Eds.), Changing perceptions : Writings on gender and development (pp. 149-157). London: Oxfam.

McGehee, N.G., Kim, K., \& Jennings, G. R. (2007). Gender and motivation for agritourism entrepreneurship. Tourism Management, 28, 1, 280-289.

Mendras, H. (1995). Les societés paysannes. Paris: Folio Histoire.

Muller, P. (2009). Le basculement du regard. La question de l'entrepreneur rural. Etudes Rurales, 183, 1, 101-112. (1987). Un métier né de la crise: exploitant rural. Sociologie du travail, 4, 479-475.

Murthy, R., Sagayan, J., Rengalakshmi, J., \& Nair, S. (2008). Gender, efficiency, poverty reduction, and empowerment: Reflections from an agriculture and credit programme in Tamil Nadu, India. Gender \& Development, 16, 1, 101-116.

Nazneen, S., Darkwah, A., \& Sultan, M. (2014). Researching women's empowerment: Reflections on methodology by southern feminists. Women's Studies International Forum, $45,55-62$.

Nicourt, C. (2014). Le lent dévoilement du travail des agricultrices. VertigO : La revue électronique en science de l'environnement, 14, 1, 1-31. Retrived on June 4th, 2015. Available at: http://vertigo.revues.org/14731; DOI : 10.4000/vertigo.14731.

Oppermann, M. (1995). Holidays on the farm: A case study of German hosts and guests. Journal of Travel Research, 34, 1, 63-67.

Ouest France. (2012). Les agricultrices agissent pour l'avenir du monde rural. Retrieved July 11, 2014. Available at : http://www.ouest-france.fr/les-agricultrices-agissent-pourlavenir-du-monde-rural-1091024 
Oxaal, Z. \& Baden, S. (1997). Gender and Empowerment : Definitions, Approaches and Implications for Policy, briefing prepared for the Swedish International Development Cooperation Agency (SIDA), Report number 040. Brighton, UK: Bridge Development - Gender, Institute of Development Studies.

Pini, B. (2004). Gender and farming in the information economy. Australian Journal of Communication, 31, 2, 135-48.

Ploeg, J.D.v.d, Renting, H., et al., (2000). Rural development: From practices and policies towards theory. Sociologia Ruralis 40, 4, 391-408.

Quetier, F., Marty, P., Lepart, J. (2005). Farmers' management strategies and land use in an agropastoral landscape: Roquefort cheese production rules as a driver of change. Agricultural Systems 84, 171-193.

Rieu, A. \& Dahache, S. (2008). S'installer comme agricultrice : Sur la socialisation et la formation sexuée en agriculture. Review of Agricultural \& Environmental Studies, 8, $3,71-94$.

. (2007). Profession agricultrice : L'invention d'un management agricole et domestique singulier. Sociologies Pratiques, 1, 14, 45-57.

Sachs, C. (1983). The invisible farmers: Women in agricultural production. Totowa, NJ: Rowman \& Allenheld.

Saugeres, L. (2002a). The cultural representation of farming landscape: Masculinity, power and nature. Journal of Rural Studies, 18, 373-384.

. (2002b). Of tractors and men: Masculinity, technology and tractors in a French farming community. Sociologia Ruralis, 42, 2, 143-159.

. (2002c). 'She's not really a woman, she's half a man': Gendered discourses of embodiment in a French farming community. Women's Studies International Forum, $25,6,641-650$.

Segalen, M. (1983). Love and power in the peasant family. Oxford: Blackwell.

Sharpley, R. \& Vass, A. (2006). Tourism, farming and diversification : An attitudinal study. Tourism Management 27, 1040-1052.

Trauger, A. (2004). 'Because they can do the work': Women farmers and sustainable agriculture. Gender, Place \& Culture, 11, 2, 289-307.

Umut Beşpiran, F. (2011). Questioning agency and empowerment: Women's work-related strategies and social class in urban Turkey. Women's Studies International Forum, 33, $6,523-532$.

Wepierre, A-S., Lerbourg, J., \& Courleux, F. (2012). Un agriculteur sur cinq a moins de 40 ans. Agreste Primeur, 293. Ministère de l'Agriculture, de l'Agroalimentaire et de la Forêt. 
1 Williams, S., Seed, J., \& Mwau, A. (1994). Oxfam Gender Training Manual. Oxford: Oxfam.

2 Wright, W. \& Annes, A. (2014). Farm Women and Agritourism: Representing a New

3 Rurality. Sociologia Ruralis, 54, 4, 477-499.

4

5 Woolf, V. (1929). A room of one's own. London: Hogarth Press.

6

7 . (1925). Mrs. Dalloway. London: Hogarth Press.

8 